ELORE (ISSN 1456-3010), vol. 15 - 2/2008.

Julkaisija: Suomen Kansantietouden Tutkijain Seura ry.

[http://www.elore.fi/arkisto/2_08/nyn2_08.pdf]

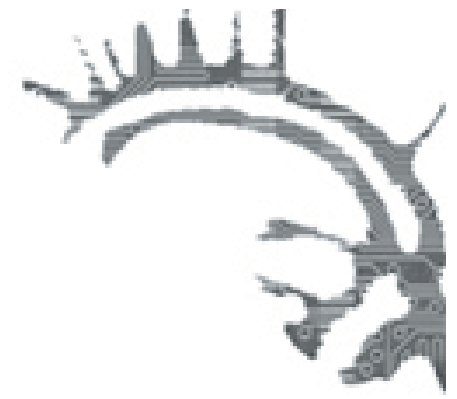

\title{
RECENSION:
}

\section{FORSKNING, KÄNSLOR OCH FÖRSTÅELSE}

\author{
Marander-Eklund, Lena \& Illman, Ruth (red.) 2007: Känslornas koreografi. \\ Reflektioner kring känsla och förståelse i kulturforskning. Hedemora: Gidlund. \\ 200 sidor.
}

\section{Peter Nynäs}

Antologin Känslornas koreografi har som syfte att lyfta fram och problematisera forskningsprocessens emotionella sidor. Avsikten är att aktualisera dels frågor om känslornas roll i forskningsprocessen och i mötet med de individer som studeras, dels hur man studerar känslor hos dessa individer och i materialet. Det är uppenbart att det handlar om kvalitativa ansatser och vidare - som redaktörerna själva inledningsvis framhåller - är detta slag av frågor motiverade mot bakgrunden av det växande intresset för känslor på flera håll inom humaniora. Att ett sådant intresse finns kan man lätt instämma i. Exempelvis hittar man inom religionsvetenskapen två nyutkomna böcker som visar på detta intresse, nämligen The Oxford Handbook of Religion and Emotion (2007) och boken Religion and Emotion: Approaches and Interpretations (2004), båda redigerade av John Corrigan och utgivna på Oxford University Press.

Det skall genast sägas att redaktörerna - och skribenterna - har gjort ett bra arbete. Liksom många andra antologier har den här artikelsamlingen sin grund i ett tvärvetenskapligt seminarium. Steget från seminarium till antologi är sällan oproblematiskt, ofta med intressanta men aningen spretiga samlingsverk som resultat. Den bristen kan den här antologin inte klandras för. Artiklarna samlar sig till en fungerande helhet som är väl strukturerad och överskådlig. Antologin inleds med frågor kring känslors roll i förståelseprocessen varefter perspektivet förskjuts till att handla om känslor i fältarbete och slutligen känslor som forskningsobjekt. Jag skall inte summera de enskilda artiklarna som är tolv till antalet. Istället vill jag visa på några sporadiskt valda exempel hur antologin i mitt tycke lyckas skapa öppningar till en fortsatt diskussion. 


\section{KÄNSLOR SOM ENGAGEMANG}

Känslor räknas traditionellt höra till de psykiska inslagen i våra liv. De har därför ofta alltför lätt överlämnats till psykologin som vetenskap att studera. Men filosoferna Camilla Kronqvist och Ylva Gustafsson rör sig delvis inne på psykologins område och exemplifierar ansatser till det slags tvärvetenskapliga gränsöverskridningar som man som läsare kan förvänta sig av antologin.

Camilla Kronqvists artikel är speciellt intressant med tanke på antologin som helhet. På ett sätt blir hon en röst för hela antologins berättigande och för vikten av att inom metodologin uppmärksamma känslor. Hon ifrågasätter nämligen just den snäva psykologiseringen av känslor, och i stället pekar hon på känslor som en intim del av det mellanmänskliga och av förståelseprocesser. Kronqvist skriver: "Hur vi beskriver andra människor och vad de gör (i meningstermer) är alltid konstituerat av hur vi själva står i förhållande till dem. Det är alltid ett uttryck för vad som är viktigt för oss. Vad vi överbuvudtaget kommer att se som fakta i dessa avseenden är beroende av våra reaktioner." (S. 42)

Det här, menar Kronqvist, innebär att våra känslor inte handlar om världen. Snarare måste känslor betraktas som en väsentlig del av vårt engagemang $\mathrm{i}$ världen. Kronqvists tanke utgör en betydelsefull och konstruktiv kontrast till de kognitiva känsloteorierna, och hennes reflektion är enkel, kärnfull och relevant. Kronqvists artikel öppnar dörren till ett sätt att förstå och kanske metodologiskt handskas med känslor inom humaniora som är betydelsefullt och som i min mening skapar en grund för antologin som helhet.

Här bör det naturligtvis understrykas att Kronqvists bidrag inte skall eller kan räknas som en allmän kritik av psykologins möjliga betydelse för den tematik som behandlas i antologin. En sådan generell kritik för Kronqvist naturligtvis inte heller fram. Däremot kan man som läsare fråga sig ifall psykologin som vetenskap kan ha en roll för en fortsatt utveckling av frågeställningen om känslor i relation till förståelseprocesser. En sådan fråga hade kunnat aktualiseras. Det ser jag inte som Kronqvists eller Gustafssons uppgift, men eventuellt som en möjlig uppgift för redaktörerna. Med tanke på antologins explicita frågeställningar hade jag kanske förväntat mig ett bidrag som tagit som sin uppgift att söka relevanta insikter från psykologin. Det här knyter naturligtvis an till frågan om samlingen filosofer, folklorister, religionsvetare och teologer kan karaktäriseras som tvärvetenskaplig.

Men - det här skall inte uppfattas som kritik. Istället handlar det om att antologin i sin ofta mycket seriösa hållning till de frågor som behandlas skapar grund för en större tvärvetenskaplig bredd. Den vare sig slår in öppna dörrar eller stänger vägar fram.

Jag skall lyfta fram en annan artikel. Betydelsen av tillit stiger ofta fram i metodlitteratur, exempelvis när det gäller intervjusituationer. Ändå är det en aspekt som sällan fördjupas längre än till några insikter som vanligen ter sig som en instrumentell check-lista. I förhållande till det här är Sofie Strandéns artikel intressant läsning när hon reflekterar kring tillitens betydelse i den egna forskningsprocessen. Det jag fäster mig vid är inte enbart de insikter om metod som förs fram i artikeln - även om de 


\section{Peter Nynäs}

i sig är viktiga. Istället är det en specifik hållning som kommer till uttryck i form av insikten om att tillit ligger utanför det man som forskare har kontroll över och att man som forskare befinner sig i ett konkret beroendeförhållande till de individer som man studerar. I metodböcker får man tyvärr ofta en idealiserad bild av den egna möjligheten att hantera tillit i till exempel intervjusituationer och därmed en förvanskad bild av det mellanmänskliga engagemang som forskning handlar om. När Strandén genom sin artikel visar på vikten av att reflektera över den mänskliga sidan av forskningsprocessen för det mina tankar till Liz Bondis artikel "The Place of Emotions in Research: From Partitioning Emotion and Reason to the Emotional Dynamics of Research Relationships" i Emotional Geographies (2005). Vad självreflektivitet innebär är inte självklart och ännu mindre hur man kommunicerar det i metodböcker.

\section{DEN KVALITATIVA HÅLLNINGENS SKUGgSIDA}

Frågan om självreflektivitet ger mig möjlighet att ta fatt i en annan frågeställning. Med bas i den viktiga insikten om känslor som engagemang i världen, som Kronqvist för fram, motiveras naturligtvis antologin som helhet när det gäller vikten av att förstå både de egna känslorna som forskare och känslor hos de individer som studeras. Men i förlängningen uppstår också frågor om den humanistiska forskningens skuggsida. Den förtjänar ytterligare kritisk reflektion: finns det en risk att den kvalitativa positionen blir så medveten om vikten av att utveckla sin lyhördhet, om vikten av balansen mellan närhet och distans, om vikten av att reflektera över moraliska implikationer av mötet med den andra och vikten av sin egen subjektivitet att det centrala dialogiska elementet inverteras? Jag tänker mig att ifall ideal så som autenticitet, direkthet, närhet och tillit blir normativa riskerar de att urholka förutsättningarna för desamma.

Kvalitativ forskning är med andra ord inte alltid harmlös i sin specifika hållning. Risken som döljer sig är en blanding av "den goda forskaren och forskningen", ett för humaniora kollektivt identitetsskapande med narcissistiska förtecken, det vill säga ett identitetsskapande som kan kolonialisera sin omgivning och den andra genom att definiera sig på ett sätt som inte ger den eller de andra något konkret utrymme. Det bryter ryggen av den andra med sin självdefinierade godhet. Den realistiska och praktiska hållning som bland annat Strandén representerar utgör en buffert mot en sådan hållning. Det gör även Bengt Kristensson Ugglas artikel som jag avslutningsvis vill lyfta fram.

Risken som jag ville peka på ovan handlar om en emotionell hållning som humaniora ibland kommer farligt nära och som därför borde uppmärksammas i lika hög grad som man problematiserar de attityder som döljer sig i distinktionen mellan forskarens objektiva och distanserade studium av sitt "objekt". Vilken karaktär har den reflexiva och dialogiskt inriktade humanistiska forskningen? Finns det specifika problem dolda i denna? På vilket sätt kan den manifestera sig som makt och kön? Det här är inte nya frågor men frågor som jag tror kan utvecklas genom den fokus som genereras i antologin Känslornas koreografi. 
Kristensson Ugglas artikel står först i antologin, men den kunde likaväl ha funnits som avslutning, eftersom den etablerar en sund balans i förhållande till de perspektiv som betonar känslornas roll i förståelseprocessen. Kristensson Uggla skriver - som en direkt kommentar till samma frågor som öppnar hela antologin - på följande sätt: 'Känslorna har visserligen en ovedersäglig produktiv betydelse för att utveckla förståelsen, men känslorna kan inte ensamma etableras som sanningsinstanser. Istället måste de förmedlas kritiskt via olika förklarande procedurer - utan att för den skull elimineras." (S. 27) En sådan kritik innebär naturligtvis i praktiken en självreflexiv hållning, men även självprövning och prövning av de känslor som man upptäcker. Vidare tror jag att det här betyder att forskningen bör vara förenad med vilja att omforma sig själv och sin position - även den "goda viljan". Känslor är aldrig oskyldiga men inte heller gjutna i sten. De är också makt och kön, och de kan ändra och ändras.

Antologins många intressanta artiklar kan man inte göra rättvisa i en recension, och det har heller inte varit min avsikt. Ovan har jag med hjälp av några exempel velat visa hur jag funnit boken givande. På ett generellt plan skriver antologin in sig i frågeställningar som handlar om svåra och vedertagna dikotomier i forskning så som närhet och distans, subjektivitet och objektivitet, känsla och förnuft och så vidare. Antologin är ett pretentiöst företag, som hanterar de frågeställningar den aktualiserar på ett seriöst sätt. Den fyller mycket väl en roll som kompletterande metodlitteratur på fördjupad nivå och för forskare.

\section{LiTTERATUR}

BONDI, LIZ 2005: The Place of Emotions in Research: From Partitioning Emotion and Reason to the Emotional Dynamics of Research Relationships. - Davidson, Joyce \& Bondi, Liz \& Smith, Mick (red), Emotional Geographies. Hampshire \& Burlington: Ashgate.

CORRIGAN, JOHN (ed.) 2004: Religion and Emotion: Approaches and Interpretations. New York: Oxford University Press.

- (ed.) 2007: The Oxford Handbook of Religion and Emotion. New York: Oxford University Press.

Teologi doktor Peter Nynäs är tf professor i religionsvetenskap vid Åbo Akademi. 